JURNAL KESEHATAN LINGKUNGAN RUWA JURAI

\title{
GAMBARAN SANITASI DAN PERILAKU PENGHUNI RUMAH PENDERITA TUBERKULOSIS DI WILAYAH KERJA PUSKESMAS KEDATON KOTA BANDAR LAMPUNG TAHUN 2021
}

Delvita Sari ${ }^{1^{*}}$

${ }^{1}$ Politeknik Kesehatan Kemenkes Tanjungkarang

Artikel Info :

Received 13 Februari 2022

Accepted 24 Februari 2022

Available online 28 Februari 2022

\section{Editor: Ahmad Fikri}

Keyword :

Tuberculosis, house components, behavior, occupants

Kata Kunci :

Tuberkulosis, sanitasi, komponen rumah, perilaku, penghuni

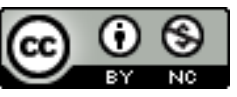

Ruwa Jurai: Jurnal

Kesehatan Lingkungan is

licensed under a Creative

Commons Attribution-

NonCommercial 4.0 International License.

\begin{abstract}
A bstract
Tuberculosis (TB) is the leading killer of infectious diseases. This disease is caused by Mycobacterium tuberculosis, and its transmission is closely related to housing quality. This study aims to describe the home sanitation of TB patients in the working area of Puskesmas Kedaton in Bandar Lampung City in 2021. This study is descriptive with a sample of 81 patient houses. The data that has been collected is processed, then analyzed descriptively, and presented in tabular form. Based on the results of the study, it is known that the components of the house that have met the requirements are occupancy density (50.6\%), humidity (46.9\%), ventilation (54.3\%), lighting (39.5), floor (79.0\%), and walls (70.4\%). It is still found that the behavior of householders who use goods simultaneously (51.9\%) and use eating utensils simultaneously (64.2\%). Residents of the house should pay attention and gradually improve the sanitary conditions of the house, separating food items and utensils between the sick and the healthy.
\end{abstract}

* Corresponding author : Delvita Sari

Jl. Soekarno-Hatta No 6, Bandar Lampung, Lampung. Indonesia.

Email: delfitasari4@gmail,com

\section{PENDAHULUAN}

Perumahan dan kawasan permukiman adalah satu kesatuan sistem yang terdiri atas pembinaan, penyelenggaraan perumahan, penyelenggaraan kawasan permukiman, pemeliharaan dan perbaikan, pencegah dan peningkatan kualitas terhadap perumahan kumuh dan pemukiman kumuh. Permukiman kumuh adalah permukiman yang tidak layak huni karena ketidakteraturan bangunan, tingkat kepadatan bangunan yang tinggi, dan kualitas bangunan serta sarana dan prasarana yang tidak memenuhi syarat. Perumahan kumuh adalah perumahan yang mengalami penurunan kualitas 
fungsi sebagai tempat hunian. Permukiman dapat terhindar dari kondisi kumuh dan tidak layak huni jika pembangunan perumahan sesuai standar yang berlaku, salah satunya dengan menerapkan persyaratan rumah sehat.

Masalah rumah dan permukiman di Indonesia terutama dikarenakan kualitas dan kuantitas yang rendah. Bukan hanya terletak pada kurangnya jumlah rumah di perkotaan tetapi menyangkut aspek kualitas rumah dan aspek non fisik, yaitu perilaku penghuni yang sangat mempengaruhi kondisi kesehatan rumah. Permukiman yang tidak layak huni banyak dijumpai di lingkungan padat penduduk pada kota-kota besar dikarenakan angka perpindahan dan mobilitas penduduk yang tinggi. Ketersediaan lahan yang sempit dengan jumlah penghuni yang tidak sesuai merupakan permasalahan yang paling banyak dijumpai dalam permukiman penduduk padat penghuni. Kurangnya pembangunan perumahan dan permukiman dapat menimbulkan berbagai masalah, antara lain: timbulnya daerah kumuh yang tidak memenuhi syarat kesehatan baik dari segi konstruksi maupun fasilitas kesehatan lingkungannya (Prasetyawati, Gravitiani, \& Sudaryanto, 2018).

Masalah kesehatan yang paling banyak diabaikan oleh masyarakat salah satunya masalah faktor lingkungan memegang peranan penting dalam penularan, terutama lingkungan rumah yang tidak memenuhi syarat. Lingkungan rumah merupakan salah satu faktor yang memberikan pengaruh besar terhadap status kesehatan penghuninya. Lingkungan rumah yang buruk dapat menimbulkan berbagai penyakit baik yang menular maupun tidak menular, salah satunya adalah penyakit TB (Purnama, 2017).

Masalah lain yang berpengaruh terhadap kejadian TB selain masalah lingkungan fisik rumah adalah faktor perilaku. Perilaku merupakan faktor yang mempengaruhi derajat kesehatan masyarakat karena sehat atau tidaknya sehat lingkungan kesehatan individu, keluarga dan masyarakat sangat bergantung pada perilaku manusia itu sendiri (Adliyani, 2015).

TB saat ini masih merupakan masalah kesehatan masyarakat baik di Indonesia maupun
Internasional. TB adalah suatu penyakit menular yang disebabkan oleh kuman Mycobacterium tuberkulosis. Indonesia merupa-kan negara ke-2 tertinggi penderita. Pada tahun 2019 jumlah kasus TB yang ditemukan di Indonesia sebanyak 543.874 kasus (Kementerian Kesehatan RI, 2019).

TB merupakan penyakit menular yang sebagian besar menyerang ke paru, tetapi dapat juga menyerang organ tubuh lainnya. Berdasarkan hasil survei prevalensi TB Indonesia tahun 2013-2014, diperkirakan prevalensi TB sebanyak 1.600 .000 kasus, insiden sebanyak 1.000.000 kasus dan mortalitas 100.000 kasus. Dengan notifikasi kasus tahun 2014 sebanyak 324.000 kasus, maka case detection TB di Indonesia hanya sekitar 32\%. Sebanyak 68\% kasus masih belum diobati atau sudah diobati tetapi belum tercatat oleh program. Hal ini memacu pengendalian TB nasional terus melakukan intensifikasi, akselerasi, ekstensifikasi dan inovasi program melalui Strategi Nasional Pengendalian TB (Dinas Kesehatan Kota Bandar Lampung, 2019).

Berdasarkan data Dinas Kesehatan Provinsi Lampung tahun 2019, penemuan kasus TB tertinggi adalah Kota Bandar Lampung (2.050 kasus laki-laki, 1.435 kasus perempuan, dan 361 kasus pada anak umur 0-14 tahun) (Dinas Kesehatan Kota Bandar Lampung, 2019). Salah satu kecamatan yang masih tinggi kasus TB adalah Kecamatan Kedaton, masuk dalam wilayah kerja Puskesmas Kedaton.

Kecamatan Kedaton terdiri dari tujuh kelurahan, yaitu Kelurahan Kedaton, Sidodadi, Surabaya, Sukamenanti, Sukamenanti Baru, Penengahan dan Penengahan Raya (Dinas Kesehatan Kota Bandar Lampung, 2019). Menurut data puskesmas, jumlah penderita TB pada tahun 2020 dengan jumlah kasus sebanyak 129 kasus (Puskesmas Kedaton, 2020). Penelitian bertujuan untuk menggambarkan kondisi sanitasi rumah dan perilaku penghuni rumah penderita TB.

\section{METODE}

Penelitian ini bersifat deskriptif, hanya menggambarkan kondisi sanitasi rumah dan perilaku penghuni rumah penderita $T B$ di wilayah kerja Puskesmas Kedaton Kota Bandar Lampung pada tahun 2020. Populasi adalah 
seluruh rumah pasien yang telah didiagnosis TB yang berdomisili di wilayah kerja Puskesmas Kedaton kota Bandar Lampung. Berdasarkan data puskesmas, jumlah kasus TB sebanyak 129 kasus. Namun sebanyak 42 penderita bertempat tinggal di luar wilayah kerja puskesmas, 3 meninggal dunia, dan 3 penderita pindah rumah (Puskesmas Kedaton, 2020). Sehingga populasi penelitian sebanyak 81 rumah. Tidak dilakukan pemilihan sampel, sehingga seluruh anggota populasi diikutkan dalam penelitian.

Pengumpulan data dilakukan dengan mendatangi setiap rumah penderita TB, melakukan wawancara, dan observasi. Dua faktor risiko dinilai dalam penelitian ini, yaitu faktor lingkungan fisik rumah (kepadatan hunian, kelembaban, ventilasi, pencahayaan, lantai, dan dinding), dan perilaku penghuni (penggunaan barang dan alat makan bersama). Data yang dikumpulkan selanjutnya diolah dan dibandingkan dengan peraturan yang berlaku.

\section{HASIL}

Hasil penelitian (Tabel 1) menunjukkan bahwa sebanyak 49,4\% rumah penderita TB dihuni dengan kepadatan hunian yang tidak memenuhi syarat. Lebih dari separuh rumah penderita TB memiliki kelembaban $(53,1 \%)$ dan pencahayaan $(60,5 \%)$ yang tidak memenuhi syarat. Sementara, hampir separuh $(45,7 \%)$ rumah memiliki ventilasi sesuai dengan syarat rumah sehat. Pada komponen lantai dan dinding, proporsi rumah tinggal yang tidak memenuhi syarat sebesar $21,0 \%$ dan $29,6 \%$.

Tabel 2 menunjukkan distribusi perilaku penghuni rumah dengan penderita TB. Sebanyak $51.9 \%$ penghuni rumah memiliki kebiasaan memakai barang secara bersamaan. Sedangkan yang memiliki kebiasaan memakai alat makan secara bersama sebanyak $64,2 \%$.

Tabel 1. Distribusi komponen lingkungan fisik rumah penderita TB

\begin{tabular}{lllll}
\hline \multirow{2}{*}{ Lingkungan Fisik Rumah } & \multicolumn{2}{c}{ Memenuhi Syarat } & \multicolumn{2}{c}{ Tidak Memenuhi Syarat } \\
\cline { 2 - 5 } & $\mathrm{f}$ & $\%$ & $\mathrm{f}$ & $\%$ \\
\hline Kepadatan Hunian & 42 & 50,6 & 39 & 49,4 \\
Kelembapan & 38 & 46,9 & 43 & 53,1 \\
Ventilasi & 44 & 54,3 & 37 & 45,7 \\
Pencahayaan & 32 & 39,5 & 49 & 60,5 \\
Lantai & 64 & 79,0 & 17 & 21,0 \\
Dinding & 57 & 70,4 & 24 & 29,6 \\
\hline
\end{tabular}

Tabel 2. Distribusi perilaku penghuni rumah penderita TB

\begin{tabular}{lllll}
\hline Komponen Perilaku Penghuni & Ya & \multicolumn{3}{l}{ Tidak } \\
\cline { 2 - 5 } & $\mathrm{F}$ & $\%$ & $\mathrm{f}$ & $\%$ \\
\hline Memakai Barang Secara Bersamaan & 42 & 51.9 & 39 & 48.1 \\
Memakai Alat Makan Secara Bersamaan & 52 & 64.2 & 29 & 35.8 \\
\hline
\end{tabular}

\section{PEMBAHASAN}

Berdasarkan hasil penelitian (Tabel 2) terdapat $49,4 \%$ rumah yang tidak memenuhi syarat kepadatan hunian. Kepadatan hunian meningkatkan risiko penularan TB. Kepadatan hunian adalah perbandingan jumlah penghuni dengan luas ruangan rumah yang ditempati responden dalam satuan meter persegi dengan persyaratan minimum Menurut Kementerian PUPR RI (2002) kepadatan penghuni diketahui dengan membandingkan luas lantai rumah dengan jumlah penghuni dengan ketentuan 9 $\mathrm{m}^{2}$ /orang. Kepadatan hunian mempunyai pengaruh besar terhadap kesehatan karena kepadatan hunian berkaitan dengan transmisi penyakit (Diniarti, Felizita, \& Hasanudin, 2019; Dotulong, R.Sapulete, \& Kandou, 2015; Mariana \& Chairani, 2017; Wildanny Nur Maulinda, Hernawati, \& Marchianti, 2021).

Ukuran luas ruangan suatu rumah erat kaitannya dengan kejadian TB paru. Kejadian TB paru paling besar dipengaruhi oleh keadaan 
rumah yang tidak memenuhi syarat luas ruangan. Semakin padat penghuni rumah akan semakin cepat pula udara di dalam rumah tersebut mengalami pencemaran. Jika di dalam rumah terdapat kasus $\mathrm{TB}_{\text {, maka penularan }}$ penyakit semakin cepat (Diniarti et al., 2019; Wildanny Nur Maulinda et al., 2021).

Berdasarkan hasil pengukuran kelembapan terdapat $46,9 \%$ rumah sudah memenuhi syarat dan $53,1 \%$ rumah tidak memenuhi syarat. Kelembapan dalam rumah akan mempermudah perkembangbiakan mikroorganisme penyebab penyakit, antara lain Mycobacterium tuberculosis (Putri, 2021; Wildanny Nur Maulinda et al., 2021). Menurut Kementerian Kesehatan RI (2011), kelembapan dalam rumah sehat adalah $40 \%$ $60 \%$. Kelembapan yang lebih dari $70 \%$ akan berpengaruh terhadap kesehatan penghuninya, karena tingginya kandungan air di udara. Lingkungan dengan kelembaban tinggi merupakan lingkungan yang mendukung kehidupan mikroorganisme (Kementerian Kesehatan RI, 2011; Putri, 2021; Wildanny Nur Maulinda et al., 2021).

Kelembaban rumah dapat dipengaruhi beberapa komponen rumah lainnya, yaitu pencahayaan, lantai dan dinding tidak kedap air. Selain melakukan perbaikan, perilaku membuka jendela setiap hari menjadi tindakan yang dapat dilakukan untuk menurunkan kelembaban dalam rumah.

Mycobacterium tuberculosis dapat bertahan hidup selama beberapa jam di tempat yang gelap dan lembab, namun akan cepat mati bila terkena sinar matahari langsung (Hasina, 2020; Nike Monintja, Finny Warouw, 2020; Sari, 2021). Rumah yang selalu membuka jendela setiap harinya dapat terhindar dari kelembapan yang tinggi, sehingga bakteri tidak akan mudah tumbuh dan berkembang. Sebaliknya, rumah yang gelap menjadi lingkungan yang potensial terhadap perkembangbiakan agent penyakit, terutama penyakit-penyakit yang ditularkan melalui udara (air borne disease).

Hasil penelitian di Kecamatan Gondanglegi, Malang menunjukkan bahwa orang yang tinggal di rumah dengan kelembapan ruangan yang tidak memenuhi syarat memiliki risiko 6 kali lebih besar menderita TB, dibandingkan yang tinggal di rumah yang kelembaban memenuhi syarat (Anggraeni, Raharjo, \& Nurjazuli, 2015).

Kelembapan udara kurang dari $40 \%$, dapat diatasi dengan membuka jendela rumah, menambah jumlah dan luas jendela rumah, dan memodifikasi fisik bangunan. Jika kelembapan udara lebih dari 60\%, maka dapat dilakukan upaya penyehatan seperti memasang genting kaca untuk menurunkan kelembapan. Bagi petugas puskesmas untuk selalu mengingatkan kepada masyarakat agar sadar akan pentingnya membuka jendela rumah setiap harinya.

Ventilasi rumah yang memenuhi syarat memiliki laju aliran 0,15-,025 m/detik (Kementerian Kesehatan RI, 2011). Ventilasi yang baik dapat diperoleh jika luas lubang ventilasi minimal $10 \%$ dari luas lantai rumah. Ventilasi berfungsi untuk membebaskan ruangan dari polutan, termasuk bakteri pathogen, serta menjaga kelembapan ruangan rumah karena adanya aliran udara yang terus menerus (Kementerian Kesehatan RI, 2011; Mariana \& Chairani, 2017; Nike Monintja, Finny Warouw, 2020; Putri, 2021; Wildanny Nur Maulinda et al., 2021).

Ventilasi yang tidak memenuhi syarat mengakibatkan berkurangnya konsentrasi oksigen dan bertambahnya konsentrasi karbondioksida yang bersifat racun bagi penghuninya. Tidak cukupnya ventilasi akan menyebabkan peningkatan kelembapan ruangan karena terjadinya proses penguapan cairan dari kulit dan penyerapan. Kelembapan yang tinggi menjadi lingkungan yang mendukung kehidupan mikroorganisme.

Pencahayaan yang baik di dalam rumah sekurang-kurangnya 60 lux (Badan Standarisasi Nasional Indonesia, 2001; Kementerian Kesehatan RI, 2011). Hasil penelitian mendapatkan $60,5 \%$ rumah yang pencahayaan tidak memenuhi syarat. Sinar matahari sangat penting masuk di dalam rumah, karena dapat menerangi ruangan, sekaligus membunuh kuman pathogen (Kementerian Kesehatan RI, 2011; Putri, 2021; Sari, 2021). Kuman TB dapat bertahan hidup di lingkungan dalam waktu yang lama, tetapi akan mati jika terkena sinar matahari, sabun, lisol, karbol dan panas api. Rumah yang tidak masuk sinar matahari mempunyai risiko menderita tuberculosis 3-7 kali 
dibandingkan dengan rumah yang dimasuki sinar matahari (Purnama, 2017).

Pada penelitian ini sebagian besar rumah tidak memenuhi syarat karena tidak membuka jendela dan menutup lubang ventilasi. Untuk itu, diperlukan upaya peningkatan pengetahuan keluarga dan masyarakat tentang rumah sehat, serta kaitannya dengan penyebaran penyakit.

Walaupun jumlahnya sedikit, namun masih ditemukan rumah dengan lantai dan dinding yang tidak memenuhi syarat kesehatan, sebesar $21,0 \%$ dan $29,6 \%$. Lantai dan dinding rumah berkaitan erat dengan kelembaban dan jumlah partikulat (debu) di udara. Lantai yang tidak kedap air menyebabkan uap air dari dalam tanah berkumpul di ruangan. Sedangkan partikel debu berasal dari lantai tanah yang terlontar akibat aktivitas penghuninya.

Kelembaban dan partikulat merupakan dua komponen utama dalam kehidupan mikroba di udara. Kelembaban tinggi akan menjaga mikroba tetap hidup, sedangkan partikel debu sebagai tempat berlindung dan sarana mobilitas. Oleh sebab itu, ruangan dengan kadar debu tinggi, juga memiiki angka kuman yang tinggi.

Dinding adalah struktur padat untuk membatasi dan melindungi. Umumnya, dinding membatasi suatu bangunan dan menyokong struktur lainnya, membatasi ruang dalam bangunan menjadi ruangan-ruangan. Dinding berfungsi sebagai pelindung dari gangguan, cuaca, serta menjaga kerahasiaan penghuninya.

Perilaku merupakan faktor kedua yang mempengaruhi derajat kesehatan masyarakat. Perilaku akan dipengaruhi oleh kebiasaan, adat istiadat, kepercayaan, pendidikan sosial ekonomi, dan perilaku-perilaku lain yang melekat pada dirinya.

Hasil penelitian mendapatkan 51.9\% penghuni rumah memiliki kebiasaan memakai barang secara bersamaan, dan 64,2\% memakai alat makan bersama. Penggunaan barang secara bersama-sama dengan penderita TB, akan meningkatkan risiko penularan penyakit. Droplet yang dikeluarkan oleh penderita saat batuk dan bersin akan menempel pada barang-barang yang ada di sekitarnya.

Menurut Moa, Zainuddin, \& Nursina (2018), salah satu langkah untuk pencegahan penularan TB adalah menghindari penggunaan barang bersama, terutama alat makan. Penderita TB dianjurkan tidak makan bersama dengan orang lain, dan perlengkapan makan yang digunakan penderita sebaiknya direbus dahulu sebelum dipakai oleh orang lain. Rekomendasi yang sama juga disampaikan oleh (Hutama, Riyanti, \& Kusumawati, 2019), bahwa salah satu bentuk pencegahan penularan TB adalah tidak saling pinjam alat mandi dan tidak menggunakan alat makan bersamaan.

\section{SIMPULAN}

Hasil penelitian mendapatkan 49,4\% penderita TB tinggal di rumah dengan kepadatan yang tinggi. Sekitar separuh rumah penderita TB tidak memenuhi syarat kesehatan, pada komponen kelembaban (53,1\%), pencahayaan $(60,5 \%)$, dan ventilasi $(45,7 \%)$. Sedangkan pada komponen lantai dan dinding, proporsi rumah tinggal yang tidak memenuhi syarat sebesar $21,0 \%$ dan $29,6 \%$. Berdasarkan perilaku penghuni, sebanyak $51.9 \%$ penghuni rumah memiliki kebiasaan menggunakan barang secara bersamaan, dan $64,2 \%$ menggunakan alat makan secara bersama. Hasil ini menunjukkan tingginya risiko penularan TB terhadap anggota rumah. Selain perbaikan konstruksi, perlu peningkatan pengetahuan keluarga dalam pencegahan penularan penyakit TB.

\section{DAFTAR PUSTAKA}

Adliyani, Z. O. N. (2015). Pengaruh Perilaku Individu terhadap Hidup Sehat. Majority, 4(7), 109114.

Anggraeni, S. K., Raharjo, M., \& Nurjazuli, N. (2015). Hubungan Kualitas Lingkungan Fisik Rumah dan perilaku Kesehatan dengan Kejadian TB Paru di Wilayah Kerja Puskesmas Gondanglegi Kecamatan Gondanglegi Kabupaten Malang. Jurnal Kesehatan Masyarakat FKM Undip, 3(21), 559-568.

Badan Standarisasi Nasional Indonesia. (2001). SNI 03-6575-2001 tentang Tata Cara Perancangan Sistem Pencahayaan Buatan pada Bangunan Gedung. In Badan Standarisasi Nasional.

Dinas Kesehatan Kota Bandar Lampung. (2019). Profile Kesehatan Kota Bandar lampung Tahun 20219. Bandar Lampung: Dinas Kesehatan Kota Bandar Lampung.

Diniarti, F., Felizita, E., \& Hasanudin. (2019). 
Pengaruh Kepadatan Hunian Rumah Dengan Kejadian Tb Paru Di Wilayah Kerja Puskesmas Basuki Rahmad Kota Bengkulu Tahun 2019. Journal of Nursing and Public Health, 7(2), 17.

Dotulong, J. F. ., R.Sapulete, M., \& Kandou, G. D. (2015). Hubungan Faktor Risiko Umur, Jenis Kelamin Dan Kepadatan Hunian Dengan Kejadian Penyakit Tb Paru Di Desa Wori Kecamatan Wori. Jurnal Kedokteran Komunitas Dan Tropik, 3(2), 57-65.

Hasina, S. N. (2020). Pencegahan Penyebaran Tuberkulosis Paru Dengan (BEEB) Batuk Efektif dan Etika Batuk Di RW. VI Sambikerep Surabaya. Community Development Journal: Jurnal Pengabdian Masyarakat, 1(3), 322-328. https://doi.org/10.31004/cdj.v1i3.1019

Hutama, H. I., Riyanti, E., \& Kusumawati, A. (2019). Gambaran Perilaku Penderita Tb Paru Dalam Pencegahan Penularan Tb Paru Di Kabupaten Klaten. Jurnal Kesehatan Masyarakat (eJournal), 7(1), 491-500.

Kementerian Kesehatan RI. Peraturan Mentri Kesehatan Indonesia No 1077/Menkes/PER/2011 Tentang Pedoman Penyehatan Udara Dalam Rumah. , (2011).

Kementerian Kesehatan RI. (2019). Profil Kesehatan Indonesia Tahun 2018 (R. Kurniawan, Y. Yudianto, B. Hardana, \& T. Siswanti, Eds.). https://doi.org/https://doi.org/10.1002/qj

Kementerian PUPR RI. Keputusan Menteri Permukiman Dan Prasarana Wilayah Nomor 403/KTPS/M/2002 Tahun 2002. Tentang Pedoman Teknis Pembangunan Rumah Sederhana Sehat. Menteri Permukiman Dan Prasarana Wilayah. , (2002).

Mariana, D., \& Chairani, M. (2017). Kepadatan Hunian, Ventilasi Dan Pencahayaan Terhadap Kejadian Tb Paru Di Wilayah Kerja Puskesmas Binaga Kabupaten Mamuju Sulawesi Barat. Jurnal Kesehatan Manarang, 3(2), 75-80.
Moa, T., Zainuddin, \& Nursina, A. (2018). Perilaku Masyarakat Terhadap Upaya Pencegahan Penularan Penyakit TB (Studi Kualitatif Di Wilayah Kerja Puskesmas Tamalanrea Jaya Kelurahan Tamalanrea Jaya Kecamatan Tamalanrea Kota Makassar). Journal Health Community Enpowerment, 1(1), 49-62.

Nike Monintja, Finny Warouw, O. R. P. P. (2020). Hubungan antara Keadaan Fisik Rumah dengan Kejadian Tuberkulosis Paru Nike. Indonesian Journal of Public Health and Community Medicine, 1(3), 94-100.

Prasetyawati, N. D., Gravitiani, E. V. I., \& Sudaryanto, S. (2018). Analisis Kondisi Sanitasi Permukiman di Kota Yogyakarta Tahun 2015 ( Analysis of Settlement of Sanitation Conditions in Yogyakarta 2015 ). Ekosains, 10(3), 29-36.

Purnama, S. G. (2017). Diktat Kuliah Penyakit Berbasis Lingkungan (p. 164). p. 164. Bali: Universitas Udayana.

Puskesmas Kedaton. (2020). Laporan Puskesmas Rawat Inap Kedaton. Bandar Lampung: Puskesmas Rawat Inap Kedaton.

Putri, R. A. (2021). Hubungan Kondisi Rumah Dengan Kejadian Ispa Di Desa Kotagajah Kecamatan Kotagajah Kabupaten Lampung Tengah. Ruwa Jurai: Jurnal Kesehatan Lingkungan, 13(2), 75. https://doi.org/10.26630/rj.v13i2.2782

Sari, R. D. (2021). Gambaran Kondisi Perumahan Di Desa Sukosari Kecamatan Baradatu Kabupaten Way Kanan. Ruwa Jurai: Jurnal Kesehatan Lingkungan, 13(1), 35. https://doi.org/10.26630/rj.v13i1.2772

Wildanny Nur Maulinda, Hernawati, S., \& Marchianti, A. C. N. (2021). Pengaruh Kelembaban Udara, Suhu Dan Kepadatan Hunian Terhadap Kejadian TB Paru. Jurnal Midwifery Zigot, 4(2), 38-40. 